\title{
Flipping to open access for survival A librarian's critical role in transforming a journal
}

A cademic librarians occupy a different location in the scholarly communication infrastructure than do scholars who research, write, and publish. That different position has implications for what we know about scholarly communication, and about the value (and labor) of open access journals. While librarians also read, write, and publish, we are also intimately involved in the buying of information. We understand that scholarship-like everything else-takes place in a broader context of capitalist distribution of resources of all kinds, including access to information. Because of this location in the scholarly communication infrastructure, librarians can play a central role in transforming market mechanisms, in part because we are often the only people who can see them.

When I joined the editorial board of Radical Teacher in 2008, I learned how much it can matter to have a librarian's perspective in the room when decisions are made about the means of the journal's production. Radical Teacher is a journal of socialist, feminist, and anti-racist teaching practice that began in print in the 1970s, part of a left political turn in the Modern Language Association.

Pitched against dominant ideologies and arguing that the classroom could be a space for liberation and political transformation, the initial board members for the journal worked independently, cutting and pasting each issue and relying on individual and institutional subscriptions to fund the costs of production. Distribution was by mail, using envelopes, stamps, and the United States Postal Service. As the journal grew, the board members sought a publisher who could assist with the production and distribution tasks of publishing, and contracted with a university press. The editors were all embedded as researchers and teachers in universities, and, to them, the university press was one of the good guys, on their side and allied with their interests in sharing research and perspectives on critical pedagogy.

However, the partnership with a university press was not working. At my first meeting, I had expected to join a rigorous and engaged conversation about politics in the academy. Instead, the discussion was about one thing: money, and not eating the rich who have a lot of it.

The journal was facing an impending bill from the university press, with which it had recently contracted to publish its issues, but it did not have the funds available to cover the debt. Subscriptions were in stark decline, most strikingly from college and university libraries. Institutional subscriptions and their higher rates had all but disappeared. For a small journal like Radical Teacher, those institutional subscriptions were its lifeblood, and the editorial board could not understand

Emily Drabinski is coordinator of library instruction at Long Island University-Brooklyn, email:emily.drabinski@ liu.edu

(C) 2016 Emily Drabinksi 
the precipitous drop in numbers. A board member suggested we undertake a direct mail campaign.

I will never forget the strangeness of that first meeting, of listening to the befuddlement of very smart people who did not understand what was happening to them. They thought the work of making a journal was simply about collecting interesting ideas and making them available to other interested people. They did not understand the material conditions of journal production, or that a political economy of scholarly publishing governed much of their individual experiences. For scholars outside the library, there is little reason to know this. In their eyes, scholarship is simply the work of reading, researching, and writing. Subscriptions were dropping because people didn't know about our journal and how great it was, and persuasion would be enough to get librarians to renew subscriptions and keep Radical Teacher afloat. Unfortunately, it had not occurred to any of them that what they were experiencing was in fact not personal but political and economic, the result of structural changes in the knowledge economy producing a set of dynamics that was quickly determining the fate of all journals, including this small socialist one.

Of course, as a librarian in the 21st century, the explanations for that decline were quite obvious to me. Libraries were engaged in serials cancellation projects as subscriptions to journals that came bundled in Big Deals were being dumped, and Radical Teacher was getting canceled everywhere. I think I had canceled it twice myself. In the face of the contemporary political economy of scholarly publishing, sending a subscription pitch in the mail, or cold-calling friends who worked in the library, would only mean kicking the can down the road, not resolving the fundamental contradiction of trying to remain afloat as a small, subscription-funded scholarly journal in a time of publishing monopolies, market contractions, escalating journal costs, and shrinking library collections budgets.

This problem of positional knowledge is an important one, and one that has implica- tions for the way we talk about open access with scholars outside the library. Just as we can ride in (and even drive!) cars without understanding how engines work, scholars can publish without ever looking under the hood of publishing. Managing an explicitly radical journal like Radical Teacher, the editors might have been expected to understand scholarship as a material practice. For Marxists, life is produced and reproduced through material conditions. Under capitalism, factors such as surplus labor and the demand for profit constrain these conditions-factors that also play into scholarly publishing as librarians experience it. When the board members didn't see their labor as such, I felt I should intervene, in order to articulate some of these practices. As a librarian, I understood and was able to explain to the other board members why people weren't buying our journal.

Ultimately, the decision to move from closed to open access was a response to economic pressures, not political or moral ones. The problem of struggling to pay our production bills brought Radical Teacher to a decision point: we had to find another way. This crisis was an opportunity to lay bare the material conditions of our own productionthat paper and ink and server space all cost money, that the market for our product was shrinking, that university presses were paying for their own reproduction through fees they were charging us.

It was also an opportunity to help the board make a decision that would align with their politics. After discussing many potential solutions, the board decided to say yes to the option I suggested: publishing with the University of Pittsburgh Libraries as an onlineonly, open access journal. Pitt has offered us invaluable structural support, including managing our OJS installation, helping us develop standard templates, and implementing a production cycle that mostly works for us. Without the knowledge of a librarian on the board, the journal would likely have sputtered and spun out, unable to maintain its bills with only a handful of generous benefactors and the occasional bake sale or house party. For 
Radical Teacher, the flip to open access has been about survival.

Radical Teacher could have stayed closed with a commercial publisher as a response to our financial difficulties. While expedient, this decision would have been at odds with the progressive, justice-oriented perspective of the journal. Articulating open access as a political value required its own extended project.

When I presented to the board as a financial solution the option of the journal going open access with a library publisher, I also argued that it was fundamentally about a social good: increased access to scholarly communication. However, those values presented a barrier to our decision for many board members. Some editors worried that if we were freely and openly available, "anyone could read us," expressing concerns about the problem of right-wing readers and the potential for cyberbullying. For them, being widely and freely available to everyone was initially a bug, not a feature. Editors believed that paywalls were meant to secure audiences and police the political boundaries of our community of writers and readers. Librarians who negotiate, teach, and build workarounds to paywalls understand them as something else: the infrastructure of securing profit of various kinds for corporations under capitalism.

Taking Radical Teacher open access meant working with scholars until they understood that scholarship requires work beyond the realm of ideas. Even though the Marxist materialists on the board understood on some level that people made the journal with their hands, it was harder for them to see that we were part of a bigger economic structure. This point became clear only when we had to make decisions about the means of our own production. The presence of a librarian was an important part of understanding those decisions as decisions that prevented us from going under altogether and from going with a commercial publisher. Instead, we flipped the journal to an open access model that benefits all of our readers and writers.

One of the most powerful results of our decision to publish as open access was the conversion of a dozen board members, who understood in a new way that their discursive work was embedded in a political economy just as subject to critique as other forms of the neoliberal, capitalist classroom-which the board had been contesting since 1975 . The shift to open access also helped us talk less about money at meetings and more about radical teaching.

Librarians can and should play a greater role in flipping existing closed journals to open access models, especially where the content of particular journals aligns well with the political values of open access. A year or so after Radical Teacher committed to open access, Susan Stryker and Paisley Currah, two renowned transgender studies scholars, started Transgender Studies Quarterly (TSQ), a journal meant to consolidate, legitimize, and lend authority to this emerging discourse. TSQ was not published as an open access journal. Instead, the editors began the journal with Duke University Press, which required them to raise $\$ 100,000$ in start-up costs to be part of their publishing program. Stryker and Currah put up a Kickstarter to help raise those funds from community members who, because of subscriptions, would then have to pay again to access the journal once it was published.

When open access advocates reached out to understand their decision-making process, the editors responded that they liked the audiences created by Duke University Press and felt the imprint could lend reputational authority to the new journal. Missing from their explanation was a sense that $T S Q$ would be emerging in a capitalist, profit-driven scholarly publishing context that the editors would need to be intentional about resisting, and that such resistance would matter-both to authors who want to publish in TSQ and to readers who want to be able to read those authors. Perhaps the presence of a librarian on the editorial board could have lead to an open access version of this important journal.

Librarians are well positioned to do the work of facilitating open access models for scholarly journals. We understand the broader context in which scholarship emerges and 
circulates, and we are skilled in explaining to users how complicated systems and structures work. Many of us are doing important work to reform our individual publishing practices, and our field has made great strides in open- ing up many of our journals. Editorial boards outside our field are promising places for us to leverage our experience and expertise. Another world is possible, and we might be the only ones in the room who know it. $\boldsymbol{n}$

("Making Cuba connections," continues from page 485)

\section{Acknowledgment}

The authors are grateful to the vision and support of key collaborators: Carrie Cooper, Tami Back, Jenny Davy, Georgie Donovan, Jay Gaidmore, and Lisa Nickel.

\section{Notes}

1. The W\&M-Cuba Connection, http:// globalvoices.wm.edu/2015/12/23/the-wm -cuba-connection-i/.

2. Ann Marie Stock is a specialist on Cuban film and media culture and has developed relationships with scholars, artists, and organizations on the island. She is the author of On Location in Cuba: Street Filmmaking during Times of Transition (UNC Press, 2009), editor of World Film Locations: Havana (Intellect, 2015), and founding director of the nonprofit
Cuban Cinema Classics, making available subtitled Cuban documentaries on DVD for libraries and cultural organizations. To learn more about the initiative, visit www. cubancinemaclassics.org.

3. The College of William \& Mary, The College Curriculum, www.wm.edu/as /undergraduate/curriculum/coll/index.php,

4. The College of William and Mary, COLL 300, www.wm.edu/as/undergraduate/curriculum/coll/300/index.php.

5. Estudiantes de Estados Unidos visitan Televisión Serrana, www.tvserrana.icrt.cu /index.php/noticias/177-estudiantes-de -estados-unidos-visitan-television-serrana.

6. Unmade in Cuba, https://libraries. wm.edu/exhibits/unmade-cuba.

7. W\&M Libraries visits Cuba, https://www. youtube.com/watch?v=jjfjYcJPI1w. $\boldsymbol{n}$

("Cuba on our minds," continues from page 487)

the Venceremos Brigades were composed of North American college students who thought the United States' approach to relations with Cuba was misguided. They sought to create "people to people" connections and effect change in government diplomacy. The Sandy Lillydahl Venceremos Brigade Photograph Collection at the University of Massachusetts-Amherst, provides an unusually candid look at what the members of these brigades did and had access to while in Cuba. The photographs document the sugar cane cutting season, a major driver of the Cuban economy. Access: http://scua.library. umass.edu/ead/muph056.html.

- Granma, Official Newspaper. This is the website of the official newspaper of the
Cuban government. In addition to current Cuban news and events, the website features stories and press releases related to topics of particular importance. Access: http://www. granma.cu.

- $14 \mathrm{y}$ Medio. This is an alternative, independent, digital newspaper founded on the island by Yoani Sanchez, a wellknown Cuban dissident. The newspaper covers international issues, as well as reporting on everyday life in Cuba. One of the sections, for example, provides the price of produce on a supermarket in Havana. The newspaper is also available in English and in a print edition featuring the previous week's reporting. Access: http:// www.14ymedio.com. $n$ 